\title{
Litter production in the Nothofagus forests of Tierra del Fuego, Argentina
}

\author{
Alicia Moretto ${ }^{12}$, Paula Mansilla ${ }^{21}$, Guillermo Martínez Pastur ${ }^{1}$, Julio Escobar ${ }^{1}$ \\ ${ }^{1}$ Universidad Nacional del Tierra del Fuego. 9410 Ushuaia, Tierra del Fuego (Argentina) \\ ${ }^{2}$ Centro Austral de Investigaciones Científicas. 9410 Ushuaia, Tierra del Fuego (Argentina)
}

\begin{abstract}
Differences in the amount of litter-fall in arboreal species constitute an important factor to understand the nutrient cycle inside a managed forest. The objective was to determine the litter production in Nothofaguspumilio (lenga), N. antarctica (ñire) and N. betuloides (guindo) forests in Tierra del Fuego. Litters was collected during the period of highest fall (February-May), sorting its components into leaves, branches, seeds and miscellaneous (flowers, valves, etc.). Leaves represented the most important component, being significantly higher in lenga (79\%) than in guindo (65\%) or ñire (54\%). Seeds also presented bigger differences, showing a behaviour inversely proportional to that of leaves: ñire (8.7\%), guindo (3.0\%) and lenga $(0.8 \%)$. No difference was detected in branches and miscellaneous. The studied forest types showed different strategies of energy distribution, for example, being deciduous or evergreen, or of mass seed production in exceptional years.
\end{abstract}

Keywords: litter production, Nothofaguspumilio, N. antarctica, N. betuloides, Tierra del Fuego.

\section{Introduction}

The accumulation of organic matter through the incorporation of vegetal litter, especially leaves, is considerable in forests. Therefore the production of humus is an important factor in the formation of the soil thus influencing the nutrient cycle significantly (Fassbender 1996). The annualreturnof organic matter and bio elements to the soil, associated under the shape of dead leaves, constitute the main process in the recycling of nutrients of these ecosystems. Pedrasa (1989) defineslitter-fall as the dead organic matter present over the mineral soil, composed by vegetable litter at different grades of decomposition, but that can still be recognisable.The production oflitter is mainly regulated by both biological and climate processes and factors although topography, soil conditions, plant species, age and forest density are also relevant (Hernández et al. 1992). In any type of forest the massive fall of dead leaves is produced seasonally, in a given time during the year. A wide span of litter-fall implies uncertainty as to the exact moment of absition of each leaf.Those species with a short absition period have a more precise moment of leaf detachment. In this way, such species can maintain the nutrients in their leaves until moments prior to detachment, giving way to higher efficiency levels in the photosynthesis and also being highly efficient in the retranslocation process(Martín et al. 1996).

In Tierra del Fuego (Argentina) Nothofagus forests cover $35 \%$ of the surface (Collado 2001) and constitute the southernmost forests of wide leaves. The genus is represented by three species: nire $(N$. antarctica (Forst.) Oerst.), lenga ( $N$. pumilio (Poepp. etEndl.) Krasser) and guindo orMagellan coigüe ( $N$. betuloides (Mirb.)Oerst.).Before studying the nutrients, decomposition and mineralization cycles it is necessary to understand the production of litterin the ecosystems under analysis. There is previous research in Tierra del Fuego and Magellan (Robinson Hernández 2000; Barrera et al. 2000; Caldentey et al. 2001), but fail to analyse or compare the different types of existing forests. Therefore, the objective of this work is to determine the production of litter-fallin the $N$. pumilio, $N$. antarctica and $N$. betuloides forests, comparing the strategies of deciduous (the first two) and evergreen (the third one) species.

\section{Materials And Methods}

Tierra del Fuego $\left(52^{\circ} 30^{\prime}-55^{\circ} 50^{\prime} \mathrm{S}, 72^{\circ}-63^{\circ} 40^{\prime} \mathrm{W}\right)$ is an archipelago located in the southernmost tip of South America. The mean annual temperature is $5-6^{\circ} \mathrm{C}$, annual amplitude is $8-10^{\circ} \mathrm{C}$, and absolute minimum is approximately $-14^{\circ} \mathrm{C}$, all at sea level, with precipitationevenly distributed throughout the year. Forests were selected from the three species studied.Theñire forest was identified atEstancia María Cristina $\left(54^{\circ} 21^{\prime 2} 28^{\prime \prime} \mathrm{S}\right.$, $\left.67^{\circ} 15^{\prime} 39^{\prime \prime} \mathrm{W}\right)$, while the other two were in the Tierra del Fuego National Park (54 $\left.50^{\prime} 42^{\prime \prime} \mathrm{S}, 68^{\circ} 32^{\prime} 24^{\prime \prime} \mathrm{W}\right)$. A stand of approximately 2 ha was chosen in each sector with the aid of satellite imaging and geo-referenced aerial photosand the support of a geographical information system (GIS). The central point of each stand was located with a GPS. Once in the central point, 16 points of origin were chosen at random in a set of polar coordinates. This system uses a double entry table, one for an azimuth angle $\left(0^{\circ}\right.$ a $\left.359^{\circ}\right)$ and a percentage $(0 \%$ to $100 \%)$ which is applied to the minimum radius of the stand. In this way, any section of the standwas likely to be sampled. In each point of origin a trap of 0.11 by $2 \mathrm{~m}$ was placed, equivalent to a surface of $0.22 \mathrm{~m}^{2}$. The litter 
was collected at least once a month during the heavy fall period (February-May) until the complete fall of leaves. Litter from the traps was oven-dried at $45^{\circ} \mathrm{C}$ until weight was constant. Each sample was then weighed and Nothofagus litter sorted into leaves, branches, seeds and miscellaneous (twigs, flowers, cupules, etc.).The data was analysed performing a simple ANOVA, after previous transformation of data when necessary. Significantly differentmeans were separated using the Tukey $(\mathrm{p}<0.05)$ test for the different parameters.

\section{Results And Discussion}

Total litter inputs were higher $(\mathrm{p}<0.05)$ in the lenga forest $\left(2,2\right.$ ton ha $\left.^{-1}\right)$, than in guindo $\left(1,8\right.$ ton ha $\left.{ }^{-1}\right)$ or ñire $\left(1,1\right.$ ton ha $\left.{ }^{-1}\right)$ (Table 1$)$ forests. These values are comparable to those found by other authors in lengaforest (Soler et al. 2015, Moretto\&MartínezPastur, 2014, Caldentey et al. 2001). Caldentey et al. (2001) reported 2.0 ton $\mathrm{ha}^{-1}$ year $^{-1}$, while Barrera et al. (2000) described values ranging between 2.7 and 3.6 ton ha ${ }^{-1}$ year $^{-1}$ in an altitudinal gradient from valley to tree-line. In the case of ñire, the only record available isthe one reported by Soler Esteban et al. (2011) with 2.17 ton $\mathrm{ha}^{-1}$ and there is no other data available for guindo. Regarding the dynamics of litter-fall,the largest fall was recorded during April-May for lenga and guindo, while in the case ofñire the largest was recorded in April (Table 1). This bigger production observed at the end of autumn, coincides with Becker (1981), who determined that the litter-fall in Chilean broadleaf forests shows a larger production in the autumn period.

Table 1.Monthly litter production (ton $\mathrm{ha}^{-1}$ ) of three Nothofagus forests in Tierra del Fuego.

\begin{tabular}{|l|l|l|l|l|l|}
\hline Forest & February & March & April & \multicolumn{1}{l|}{ May } & \multicolumn{1}{l|}{ Total } \\
\hline Lenga & $0,23 \pm 0,02 \mathrm{a}$ & $0,18 \pm 0,02 \mathrm{a}$ & $0,86 \pm 0,04 \mathrm{a}$ & $0,88 \pm 0,04 \mathrm{a}$ & $2,17 \pm 0,08 \mathrm{a}$ \\
\hline Ñire & $0,21 \pm 0,01 \mathrm{a}$ & $0,08 \pm 0,01 \mathrm{~b}$ & $0,66 \pm 0,09 \mathrm{ab}$ & $0,14 \pm 0,02 \mathrm{~b}$ & $1,10 \pm 0,11 \mathrm{~b}$ \\
\hline Guindo & $0,34 \pm 0,07 \mathrm{a}$ & $0,23 \pm 0,11 \mathrm{a}$ & $0,57 \pm 0,03 \mathrm{~b}$ & $0,64 \pm 0,06 \mathrm{c}$ & $1,78 \pm 0,08 \mathrm{c}$ \\
\hline
\end{tabular}

Mean $\pm 1 S E(n=16)$. Within a column means followed by the same letter are not significantly different $(P>0.05)$.

A different behaviour was seen in the different components of litter (Table 2). The comparison among the three forests showed differences $(\mathrm{p}<0.05)$ in the production of leaves and seeds, while branches and miscellaneous showed no difference ( $p>0.05$ ). Leaves comprised the most important fraction of the litter-fall, as have been found in most of the forest ecosystems (Lowman 2001,Lebret et al. 2001; Santa Regina and Tarazona 2001).

Table 2.Production of litter components (ton ha ${ }^{-1}$ ) of three Nothofagus forests in Tierra del Fuego.

\begin{tabular}{|l|l|l|l|l|}
\hline Forest & Leaves & \multicolumn{1}{l|}{ Branches } & Seeds & Miscellaneous \\
\hline \multicolumn{5}{|l|}{} \\
\hline Lenga & $1,72 \pm 0,06 \mathrm{a}$ & $0,20 \pm 0,02 \mathrm{a}$ & $0,02 \pm 0,003 \mathrm{a}$ & $0,20 \pm 0,02 \mathrm{a}$ \\
\hline Nire & $0,61 \pm 0,07 \mathrm{~b}$ & $0,13 \pm 0,02 \mathrm{a}$ & $0,09 \pm 0,01 \mathrm{~b}$ & $0,26 \pm 0,02 \mathrm{a}$ \\
\hline Guindo & $1,23 \pm 0,06 \mathrm{c}$ & $0,18 \pm 0,02 \mathrm{a}$ & $0,06 \pm 0,009 \mathrm{c}$ & $0,31 \pm 0,08 \mathrm{a}$ \\
\hline
\end{tabular}

Mean $\pm 1 S E(n=16)$. Within a column means followed by the same letter are not significantly different $(P>0.05)$.

Leavesin lenga forests represent $79 \%$ of total litter-fall, with larger presence during the months of April and May. In the case of nirethe input of leaves is much lower, representing only $54 \%$ of total litter-fall, with larger absition occurring in April. On the other hand, in the guindo forest, leaves represent $65 \%$ of litter-fall, recording the largest fall in April and May (Fig. 1A). The amount of leaf percentages (68\% al 82\%) in lenga forests coincide with those monitored by Barrera et al. (2000) for an analysis along an altitudinal gradient.

Seeds comprise the least amount of dry matter in litter-fall, with a $0.9 \%$ forlenga, $8.2 \%$ forñireand $3.4 \%$ forguindoforests (Table 2). In guindoand lenga forests the larger fall of seeds occurred in May, whereas inñire the largest fall was registered in April (Fig. 1B). Seeding cycles have been described in several forest species (Kelly 1994, Kelly et al. 2000, Koenig and Knops 2000) and have received considerable attention in Nothofagus forests (Monks and Kelly 2006), because the level of variation among years is especially high (Kelly 1994, Kelly and Sork 2002). In lenga, such frequency is close to 7 years with yields reaching up to 15 million seeds perhectare in primary forests (Schmidt 1995). Therefore, the production of seeds in lenga forests this year can be considered as a year of medium-low production $\left(1.1\right.$ million seeds $\left.\mathrm{ha}^{-1}\right)$. In the case of guindo, the production observed reached 15.6 million seeds $\mathrm{ha}^{-1}$;no other research is available. In ñire the high percentage of seeds (59.1 million of seeds ha $\left.{ }^{-1}\right)$ could be associated with a year of exceptional production. Seed production in ñire in Santa Cruz (Argentina) varied between years and was related to the site quality of stands between 2 and 52 million ha ${ }^{-1}$ (Peri personal communication). In Tierra del Fuego,Soler Esteban et al. (2011) recorded a maximum production of 28.1 million seedsha ${ }^{-1}$. However, it should be noted thatñire seeds (636 mil $\left.\mathrm{kg}^{-1}\right)$ are smaller than guindo's $\left(265 \mathrm{mil} \mathrm{kg}^{-1}\right)$ and lenga's $\left(60 \mathrm{mil} \mathrm{kg}^{-1}\right)$. Branches represented $9.2 \%$ of total 
production in lenga, $11.8 \%$ in ñire and $10.1 \%$ in guindo. Both lengaand guindosaw the largest fall of branches in May; unlike ñirewhich had it in April (Fig. 1C). Miscellaneous, unlike the other compartments, had the maximum production in February, month after which production decreased considerably. The three species showed the same tendency (Fig. 1D). There is a differential compartment in the species ofNothofagusin terms of quantity and proportion of leaves and seeds fallen. The studied forest types showed different strategies of energy distribution, for example, being deciduous or evergreen, or of mass seed production in exceptional years.

Figure 1.Monthly leaves, seed, branches and miscellaneous fall of three Nothofagus forest in Tierra del Fuego. Mean \pm 1 SE $(n=16)$.
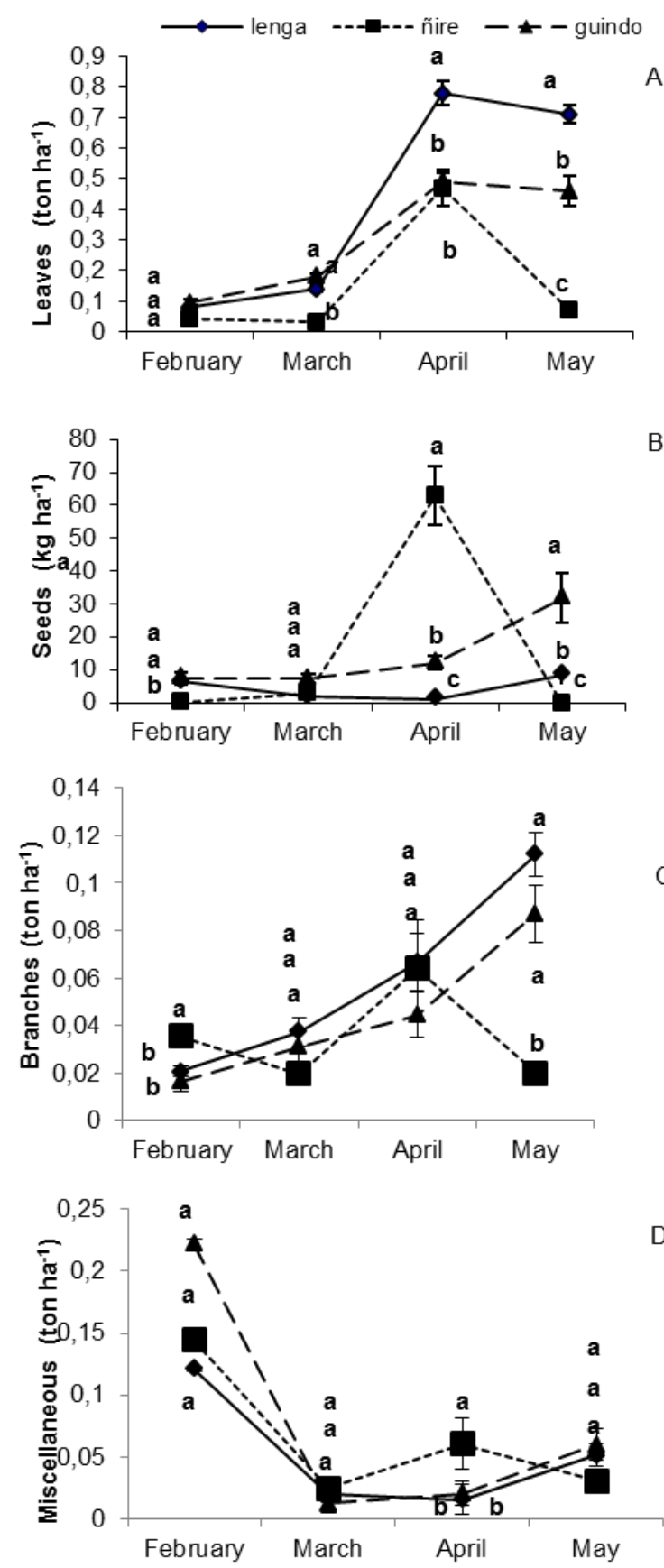

\section{Acknowledgments}

We thank the support and collaboration from the Tierra del Fuego Natural Resources Department, Tolhuin delegation, and INTA (Agro Technology National Institute), Ushuaia delegation, for the elaboration of this work and alsowish to thank Mr. Uwe Mueller who contributed with funds for the elaboration of field samplers. 


\section{References}

[1] Barrera M, Frangi J, Richter L, Perdomo M, Pinedo L. 2000. Structural and functional changes in Nothofaguspumilio forests along an altitudinal gradient in Tierra del Fuego, Argentina.Journal of VegetationScience 11: 179-188.

[2] Becker J. 1981.Estudio de producción de litter en bosques latifoliados del sur de Chile. Tesis de Grado. Facultad de Ingeniería Forestal. Universidad Austral de Chile. 181 p.

[3] Caldentey J, Ibarra M, Hernández J. 2001. Litter fluxes and decomposition in Nothofaguspumilio stands in the region of Magallanes, Chile. ForestEcology and Management 148: 145-157.

[4] Collado L .2001. Los bosques de Tierra del Fuego. Análisis de su estratificación mediante imágenes satelitales para el inventario forestal de la provincia. Multequina 10: 01-16.

[5] Fassbender HW. 1996. Modelaje de la Fertilidad del suelo y de la Productividad de Sistemas de Producción Agropecuarios en América Latina. Conferencia del XIII Congreso Latinoamericano de la Ciencia del Suelo. Aguas de Lindota (San Pablo) Brasil. 55$68 p$

[6] Hernández IM, Santa Regina I, Gallardo JF.1992.Dinámica de la descomposición de la hojarasca forestal en bosques de la Cuenca del Duero (Provincia de Zamora): Modelización de la pérdida de peso. Arid Soil Research and Rehabilitation 6: 339 -355.

[7] Kelly D. 1994. The evolutionary ecology of mast seeding.Trends in Ecology \& Evolution 9, 465-470.

[8] Kelly D, Harrison AL, Lee WG, Payton IJ, Wilson PR, Schauber EM. 2000. Predator satiation and extreme mast seeding in 11 species of Chionochloa (Poaceae). Oikos 90, 477-88.

[9] Kelly D, Sork VL. 2002. Mast seeding in perennial plants: Why, How, Where? Annual Review of Ecology and Sistematics 33:427447.

[10] Koening WD, Knops JMH. 2000. Patterns of annual seed production by northern hemisphere trees: a global perspective. American Naturalist 155, 59-69.

[11] Lebret M, Nys C, Forgeard F. 2001. Litter production in an Atlantic beech (Fagus sylvatica L.) time sequence. Annals of Forest Science 58 (2001) 755-768.

[12] Lowman M. 2001. Litterfall and leaf decay in three australian rainforest formations. Journal of Ecology 76, 451-465.

[13] Martín A, Santa Regina I, Gallardo JF.1996.Eficiencia, retraslocación y balance de nutrientes en bosques de Quercuspyrenaica bajo diferentes pluviometría en la Sierra de Gata (Centro-Oeste Español). Ecología. 10: 79-93.

[14] Monks A, Kelly D. 2006. Testing the resource-matching hypothesis in the mast seeding tree Nothofagus truncate (Fagaceae). Austral Ecology 31, 366-375.

[15] Moretto, A. S., \& Martínez Pastur, G. J. (2014). Litterfall and leaf decomposition in Nothofaguspumilio forests along an altitudinal gradient in Tierra del Fuego, Argentina.Journal of Forest Science, 60, 2014 (12): 500-510.

[16] Pedrasa M.1989. Producción de biomasa y circulación de nutrientes en un rodal de Nothofagusalessandrii (Ruil) en la zona de Constitución. Memoria de Título. Escuela de Cs. Forestales. Universidad de Chile. 112 p.

[17] Robinson Hernández OJ. 2000. Modificaciones en el aporte y descomposición de hojarasca por la intervención silvícola en bosques naturales de lenga (Nothofaguspumilio). Tesis de Grado. Facultad de Ciencias Forestales.Universidad de Chile. 95 p.

[18] Santa Regina I, Tarazona T .2001.Nutrient pools to the soil through organic matter and throughfall under a Scots pine plantation in the Sierra de la Demanda, Spain. European Journal of Soil Biology 37 (2001) 125-133.

[19] Schmidt H, Caldentey J, Donoso S. 1995. Informe 1995: Investigación sobre el manejo de la lenga - XII Región. Universidad de Chile - CONAF. 40 p.

[20] Soler, R., Pastur, G. M., Lencinas, M. V., \& Peri, P. L. (2015). Mistletoes and epiphytic lichens contribute to litter input in Nothofagusantarctica forests. ActaOecologica, 68, 11-17.

[21] Soler Esteban R, Martínez Pastur G, Lencinas MV, Peri PL .2011. Flowering and seeding patterns in primary, secundary and silvopastoril managed Nothofagusantarctica forests in South Patagonia. New Zealand Journal of Botany 48:2, 63-73.

[22] Wardle JA .1984. The New Zealand beeches: ecology, utilization and management. New Zealand Forest Service. Caxton Press, Christchurch, New Zealand. 447 p. 